\title{
Anti-tumor effects of herbal medicines on endometrial carcinomas via estrogen receptor- $\alpha$-related mechanism
}

\author{
ZENGLIN LIAN $^{1}$, KENJI NIWA ${ }^{1}$, KYOKO ONOGI ${ }^{1}$, HIDEKI MORI $^{2}$, \\ ROSANNE C. HARRIGAN ${ }^{3}$ and TERUHIKO TAMAYA ${ }^{1}$
}

\begin{abstract}
Departments of ${ }^{1}$ Obstetrics and Gynecology, and ${ }^{2}$ Pathology, Gifu University School of Medicine, 1-1 Yanagido, Gifu-city 501-1194, Japan; ${ }^{3}$ Complementary and Alternative Healthcare, John A. Burns School of Medicine,

University of Hawaii, 1960 East-West Road, Honolulu, HI 96822-2319, USA
\end{abstract}

Received March 7, 2005; Accepted May 10, 2005

\begin{abstract}
This study was performed to examine the relationship between the anti-tumor effects of herbal medicine and endometrial carcinoma with ER-related mechanisms. An endometrial cancer cell line (Ishikawa) was used for this study. The cell viability and expression of estrogen receptors (ER) were determined by MTT and RT-PCR. A dosedependent decrease of viability and apoptosis of the cancer cells was generated by exposure to the herbal medicines, Juzen-taiho-to or Shimotsu-to. The expression of ER- $\alpha$ mRNA, but not ER-ß mRNA was suppressed by Juzen-taiho-to or Shimotsu-to in an endometrial cancer cell line. The antitumor effect of these herbal medicines against endometrial carcinoma might be correlated to the ER- $\alpha$ related mechanism.
\end{abstract}

\section{Introduction}

We have reported that Juzen-taiho-to has a preventive effect on endometrial carcinogenesis in mice (1). In our subsequent study, the main component of the agent, Shimotsu-to, was found to relate to the suppression of expression of estrogenstimulated genes in mice uteri $(2,3)$. Originally, Juzen-taiho-to, which contained Shimotsu-to, Shikunshi-to and two other oriental drugs have been reported to relate to the induction of cytokine (4), antibody (5) and anti-tumor activity (6-8). Juzen-taiho-to is reported to show an anti-metastatic effect in an animal model (9). Another agent, Shikunshi-to, is described as a modulator of hematopoiesis and immune response in vitro (10).

Meanwhile, it is known that estrogen usually exerts its biological function via estrogen receptor (ER)-related

Correspondence to: Dr Kenji Niwa, Department of Obstetrics and Gynecology, Gifu University School of Medicine, 1-1 Yanagido, Gifu-city 501-1194, Japan

E-mail: kniwa@cc.gifu-u.ac.jp

Key words: herbal medicine, endometrial carcinoma, estrogen receptor mechanism(s). The two isoforms of ERs, ER- $\alpha$ and ER- $\beta$, are distributed differentially in various tissues $(11,12)$. It is suggested that they act as co-activators of estrogen binding with the estrogen-responsive element (ERE) included in estrogenresponsive genes, thereby influencing the transcriptional effects of target genes. In our previous studies, the longterm (29 weeks) exposure of E2 (5 ppm) and N-methyl-Nnitrosourea induced a high incidence of endometrial carcinoma in mice. The expression of c-fos/jun genes was overexpressed by estrogen exposure. The preventive effects of Juzen-taiho-to and Shimotsu-to on E2-related endometrial carcinogenesis were reported to relate to decreased expression of c-fos/jun. We used an in vitro study to confirm the ER-mediated mechanism for the preventive effect of Juzen-taiho-to, Shimotsu-to and Shikunshi-to.

\section{Materials and methods}

Chemicals. 17ß-E2 was purchased from Sigma Chemical Co. (St. Louis, MO), and Juzen-taiho-to, Shimotsu-to and Shikunshi-to were purchased from Tsumura Co. (Tokyo, Japan). For the in vitro study, agents were dissolved in Eagle's minimal essential medium and passed sequentially through a $0.45 \mu \mathrm{m}$ filter sterilization, then $10 \%$ fetal bovine serum was added. Five doses $(0.25,0.5,1.0,2.5$ and 5.0 $\mathrm{mg} / \mathrm{ml}$ ) were used for the exposure of each agent to the cell culture.

Cell line and cell culture. An endometrial cancer cell line of Ishikawa cells was used. Cells were cultured in MEM for $24 \mathrm{~h}$, treated with the herbal medicines and maintained at $37^{\circ} \mathrm{C}$ in a humidified $5 \% \mathrm{CO}_{2} / 95 \%$ air atmosphere. After 12, 24, 48 and $72 \mathrm{~h}$ culture, the cells were washed twice with phosphatebuffered saline (PBS) and used for the following experiments.

Cancer cell viability. The $50 \%$ inhibition concentration $\left(\mathrm{IC}_{50}\right)$ and cell viability were determined by MTT assay. After different treatments with herbal medicines, the cells $\left(1 \times 10^{4}\right)$ were washed with PBS and incubated in $10 \mu 1$ of $5 \mathrm{mg} / \mathrm{ml}$ MTT [3-(4,5-dimethyl thizol-2-yl)-2.5-diphenyl terazolium bromide] dissolved in PBS for $4 \mathrm{~h}$. One hundred $\mu \mathrm{l}$ of the dissolved solution (34 $\mu \mathrm{l}$ of HCI with $9.966 \mathrm{ml}$ isopropanol) 
Table I. Sequences of the primers and PCR conditions.

\begin{tabular}{lll}
\hline Primers & Nucleotide sequences & PCR conditions \\
\hline ER- $\alpha$ & Sense 5'-TGTGCAATGACTATGCTTCA-3' & $1 \mathrm{~min}$ at $94^{\circ} \mathrm{C}, 1 \mathrm{~min}$ at $54^{\circ} \mathrm{C}$ and $1.5 \mathrm{~min}$ at \\
& Anti-sense 5'-GCTCTTCCTCCTGTTTTA-3' & $72^{\circ} \mathrm{C}, 35 \mathrm{cycles}$ \\
ER-ß & Sense 5'-GTCCATCGCCAGTTATCACATC-3' & $45 \mathrm{sec}$ at $94^{\circ} \mathrm{C}, 45 \mathrm{sec}$ at $56^{\circ} \mathrm{C}$ and $1.5 \mathrm{~min}$ at \\
& Anti-sense 5'-GCCTTACATCCTTCACACGA-3' & $72^{\circ} \mathrm{C}, 30 \mathrm{cycles}$ \\
\multirow{2}{*}{-actin } & Sense 5'-ATCTGGCACCACACCTTCTACAATGAGCTGCG-3' & $1 \mathrm{~min}$ at $95^{\circ} \mathrm{C}, 1 \mathrm{~min}$ at $63^{\circ} \mathrm{C}$ and $2 \mathrm{~min}$ at \\
& Anti-sense 5'-CGTCATACTCCTGCTTGCTGATCCACATCTGC-3' & $72^{\circ} \mathrm{C}, 35 \mathrm{cycles}$ \\
\hline
\end{tabular}

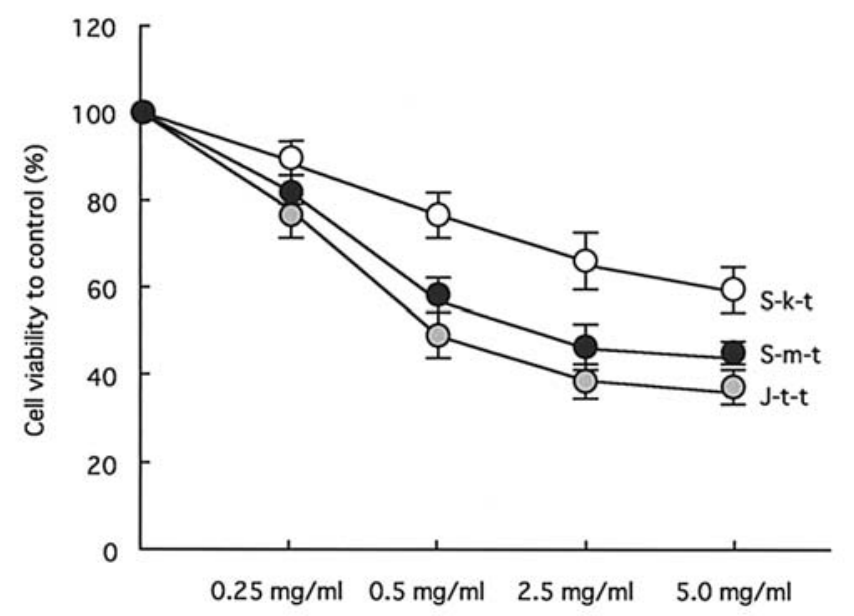

Figure 1. Viability of the Ishikawa cells. The growth of Ishikawa cells was significantly inhibited by $\mathrm{J}-\mathrm{t}-\mathrm{t}$ and $\mathrm{S}-\mathrm{m}-\mathrm{t}$. The value of the cell viability is mean $\pm \mathrm{SD}$ of five determinations.

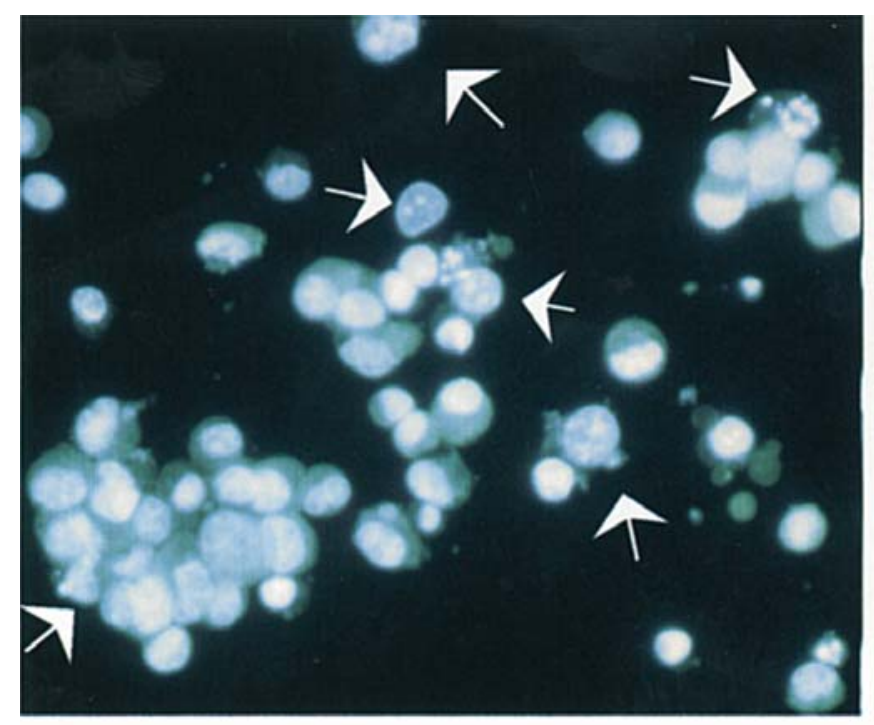

Juzen-taiho-to Group was then added to the cells. Absorbance of the dissolved solution was measured using the Easy Reader EAR 400 (SLT-Labin Struments, Austria) at 550 and $620 \mathrm{~nm}$. The absorbance without treatment was designated as $100 \%$.

Apoptosis assay. As described in our previous study, $1 \times 10^{5}$ cells were exposed to the herbal medicines for $48 \mathrm{~h}$, then collected and centrifuged at $400 \mathrm{xg}$ for $5 \mathrm{~min}$ (13). The sediment was dissolved in $100 \mu 1$ of cell fixing solution (10\% glutaraldehyde) for $30 \mathrm{~min}$, then mixed with $1 \mathrm{ml}$ PBS and centrifuged. The sediment was stained with $20 \mu 1$ PBS and $4 \mu 1$ staining solution (1 mM Hoechist 33258 in PBS). The nuclear morphology of cells in one drop on a glass slide was observed under a fluorescence microscope.

Reverse transcription-polymerase chain reaction ( $R T-P C R)$. Total RNA was isolated from cells by a guanidium thiocyanatephenol-chloroform extraction method (14). Total RNA (3 $\mu \mathrm{g})$ was reverse transcribed with Moloney murine leukemia virus reverse transcriptase (MMLV-RTase, 200 units; Gibco BRL, Gaithersburg, MD) in $20 \mu \mathrm{M}$ Tris- $\mathrm{HCl}$ buffer ( $\mathrm{pH} 8.4$ ) with

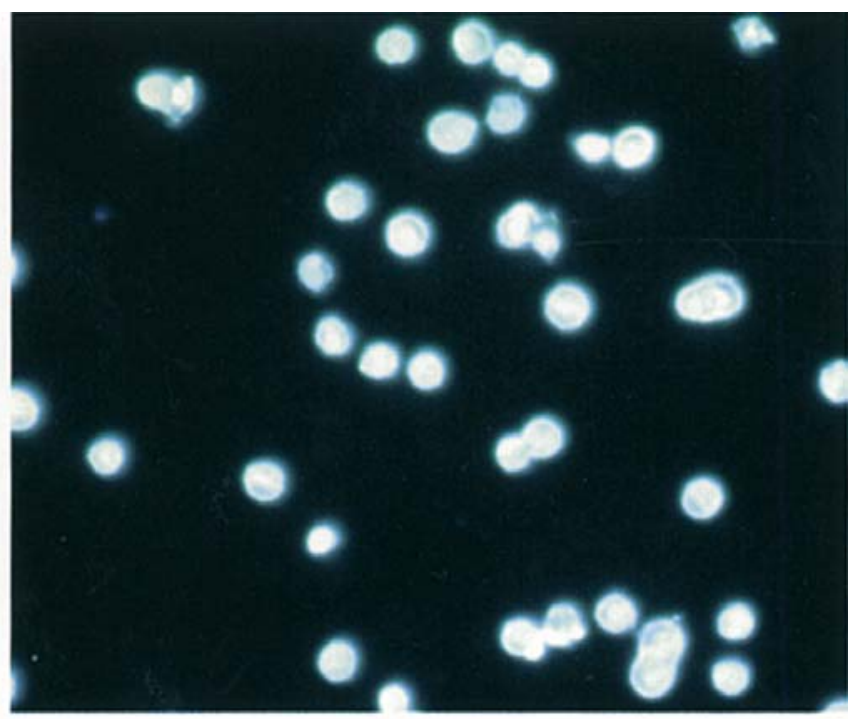

Control Group

Figure 2. Cancer cell apoptosis. Apoptotic cells were detected by imunohistochemical staining method in the J-t-t group and compared with the control group. 

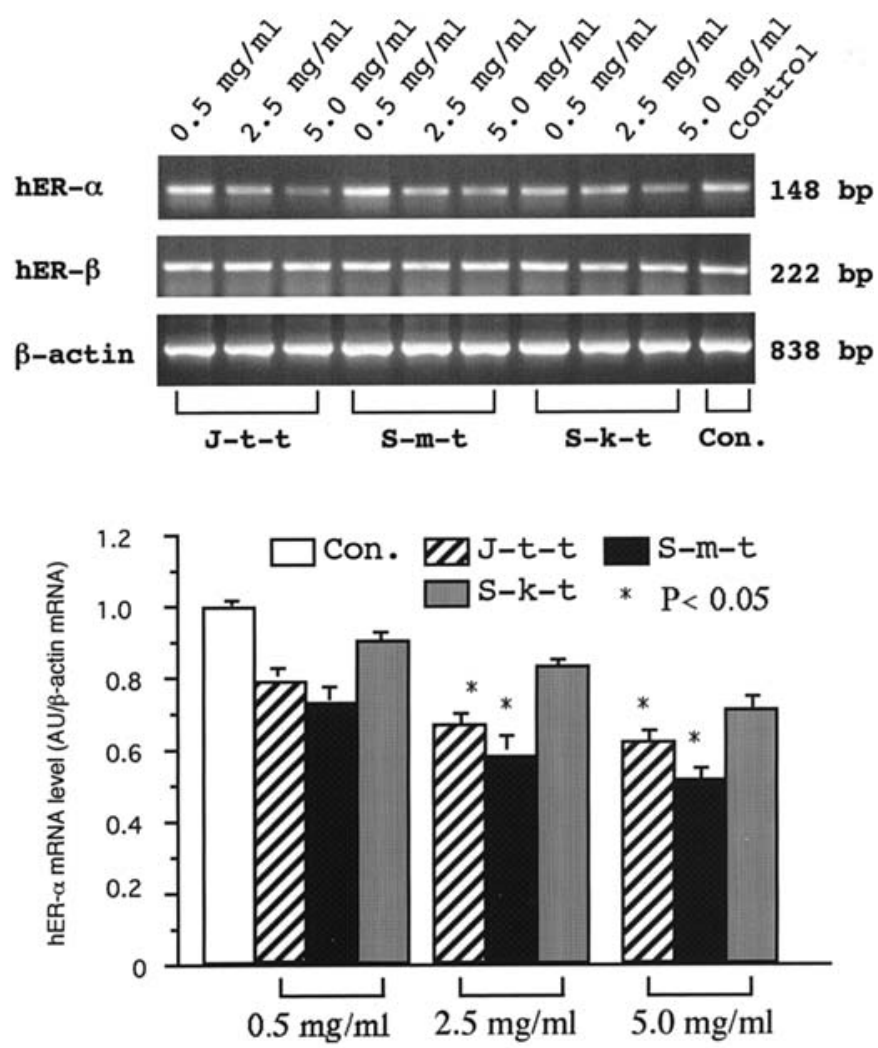

Figure 3. Expression of hER- $\alpha$ and hER- $\beta$ RNA in Ishikawa cells are shown at various doses. The bands are representative of five determinants. The hER- $\alpha$ mRNA level (AU/ß-actin mRNA) was calculated from each of the five determinations. At doses of 2.5 and $5.0 \mathrm{mg} / \mathrm{ml}$, both $\mathrm{J}-\mathrm{t}-\mathrm{t}$ and $\mathrm{S}-\mathrm{m}-\mathrm{t}$ significantly suppressed the expression of ER- $\alpha(\mathrm{p}<0.05)$, but S-K-t did not. Meanwhile, hER-ß expression was not affected by the herbal medicines.

$50 \mu \mathrm{M} \mathrm{KCl}, 2.5 \mu \mathrm{M} \mathrm{MgCl}_{2}, 0.1 \mu \mathrm{g} / \mathrm{ml}$ bovine serum albumin, $10 \mu \mathrm{M}$ dithiothreitol, and $0.5 \mu \mathrm{M}$ deoxynucleotides to generate cDNAs, using random hexamers (50 ng; Gibco BRL) at $37^{\circ} \mathrm{C}$ for $60 \mathrm{~min}$. RT reaction was heated at $94^{\circ} \mathrm{C}$ for 5 min to inactivate MMLV-RTase. The PCR conditions and primer sequences of hER- $\alpha$, hER- $\beta$ (15) and $\beta$-actin (13) are described in Table I and were carried out in reverse transcribed cDNAs with $0.1 \mathrm{mM}$ specific primers described below, using an Iwaki thermal sequencer TSR-300 (Iwaki Glass, Tokyo) with Vent DNA polymerase (New England Biolabs, Beverly, $\mathrm{MA})$ in $20 \mu \mathrm{M}$ Tris- $\mathrm{HCl}$ buffer (pH 8.8) with $10 \mu \mathrm{M} \mathrm{KCl}$, $10 \mu \mathrm{M}\left(\mathrm{NH}_{4}\right)_{2} \mathrm{SO}_{4}, 2 \mu \mathrm{M} \mathrm{MgSO}{ }_{4}, 0.1 \%$ Triton $\mathrm{X}-100$, and $0.15 \mu \mathrm{M}$ deoxynucleotide phosphates.

Statistical analysis. The analysis was performed according to the $\chi^{2}$ test or Student's $t$-test.

\section{Results}

Cell viability and apoptosis. As shown in Fig. 1, viability of Ishikawa cells was decreased dose-dependently by the addition of herbal medicines. $\mathrm{IC}_{50}$ of Juzen-taiho-to, Shimotsu-to and Shikunshi-to on day 3 were $0.49 \pm 0.02$, $0.53 \pm 0.01$ and $0.65 \pm 0.03 \mathrm{mg} / \mathrm{ml}$, respectively. Apoptosis of Ishikawa cells was confirmed with a fluorescence microscope after exposure to Juzen-taiho-to (Fig. 2).
Suppression of ER- $\alpha \mathrm{mRNA}$ and protein. After $72 \mathrm{~h}$ treatment with Juzen-taiho-to and Shimotsu-to ( 2.5 and $5 \mathrm{mg} / \mathrm{ml}$ ), the mRNA expression of hER- $\alpha$, but not hER- $\beta$ in Ishikawa cells was significantly suppressed $(p<0.05)$, while Shikunshi-to had no effect (Fig. 3).

\section{Discussion}

It was shown that Juzen-taiho-to and Shimotsu-to have a preventive effect on E2-related endometrial carcinogenesis in mice (1-3). Thus, chemopreventive effects by Juzen-taiho-to or Shimotsu-to on endometrial carcinogenesis are suggested to relate to the suppression of ER- $\alpha$ (18).

We have also reported that the inhibitory effects of herbal medicines like Juzen-taiho-to or Shimotsu-to on c-fos/jun, recognized as estrogen-responsive genes, may be related to the suppression of ER- $\alpha$. Therefore, the preventive effects of Shimotsu-to and Juzen-taiho-to on E2-induced mouse endometrial carcinogenesis may occur via the ER-mediated pathway.

In this study, Juzen-taiho-to, Shimotsu-to and Shikunshi-to suppressed the expression of ER- $\alpha$ and inhibited the growth of Ishikawa cells. Such anti-tumor effects of these agents is suggested to relate to the generation of cellular apoptosis. Juzen-taiho-to and Shimotsu-to induced cancer cell apoptosis and suppressed the expression of ER- $\alpha$ in vitro, suggesting that such herbal medicines exert anti-tumor effects on endometrial carcinoma via the ER- $\alpha$ related mechanism.

\section{Acknowledgements}

This work was supported in part by a Grant-in-Aid for Scientific Research from the Japan Society for the Promotion of Science.

\section{References}

1. Niwa K, Hashimoto M, Morishita S, Lian Z, Mori H and Tamaya T: Preventive effects of Juzen-taiho-to on N-methyl-Nnitrosource and estradiol-17ß-induced endometrial carcinogenesis in mice. Carcinogenesis 22: 587-591, 2001.

2. Lian Z, Niwa K, Gao J, Tagami K, Hashimoto M, Yokoyama Y, Mori $\mathrm{H}$ and Tamaya T: Shimotsu-to is the agent in Juzen-taiho-to responsible for the prevention of endometrial carcinogenesis in mice. Cancer Lett 182: 19-26, 2002.

3. Tagami K, Niwa K, Lian Z, Gao J, Mori H and Tamaya T: Preventive effects of Juzen-taiho-to on endometrial carcinogenesis in mice is based on Shimotsu-to constituent. Biol Pharm Bull 27: 156-161, 2004.

4. Kubota A, Okamura S, Shimoda K, Harada N, Omori F and Niho Y: A traditional herbal medicine, Juzen-taiho-to, augements the production of granulocyte/macrophage colony-stimulating factor from human peripheral blood mononuclear cells in vitro. Int J Immunother 8: 191-195, 1992.

5. Hamada M, Fujiki Y, Yamamoto H, Miyazawa Y, Shui SM, Tung YC and Yamaguchi N: Effect of a kampo medicine, juzentaihoto, on the immunoreactivity of tumor bearing mice. $\mathrm{J}$ Ethno Pharma 24: 311-320, 1991.

6. Maruyama H, Takemoto N, Maruyama N, Komatsu Y and Kawamura H: Antitumor effect of juzentaiho-to, a Kampo medicine, combined with surgical excision of trasplanted Meth-A fibrosarcoma. Int J Immunother 9: 117-125, 1993.

7. Haranaka R, Hasegawa R, Nakagawa S, Sakurai A, Satomi N and Haranaka K: Antitumor activity of combination therapy with traditional Chinese medicine and OK432 or MMC. J Biol Response Mod 7: 77-90, 1988.

8. Sugiyama K, Ueda H, Ichiko Y and Yokota M: Improvement of cisplatin toxicity and lethality by Juzen-taiho-to in mice. Biol Pharm Bull 18: 53-58, 1995. 
9. Onishi Y, Yamaura T, Tauchi K, Sakamoto T, Tsukada K, Nunome S, Komatsu Y and Saiki I: Expression of the antimetastatic effect induced by Juzen-taiho-to is based on the content of Shimotsu-to constituents. Biol Pharm Bull 21: 761-765, 1998.

10. Tseng J and Li TL: Si-jun-zi-tang regulate granulocyte macrophage colony-stimulating factor secretion by human peripheral blood mononuclear cells. Am J Chin Med 24: 45-52, 1996.

11. Gustafsson JA: Estrogen receptor beta. A new dimension in estrogen mechanism of action. J Endocrinol 163: 379-383, 1999.

12. Taylor AH and Al-Azzawi F: Immunolocalisation of oestrogen receptor beta in human tissues. J Mol Endocrinol 24: 145-155, 2000.

13. Lian Z, Niwa K, Gao J, Tagami K, Mori H and Tamaya T: Association of cellular apoptosis with anti-tumor effects of the Chinese herbal complex in endocrine-resistant cancer cell line. Cancer Detect Prev 27: 147-154, 2003.

14. Chomczynski P and Sacchi N: Single-step method of RNA isolation by acid guanidinium thiocyanate-phenol-chloroform extraction. Anal Biochem 162: 156-159, 1987.
15. Bhat KP and Pezzuto JM: Resveratrol exhibits cytostatic and antiestrogenic properties with human endometrial adenocarcinoma (Ishikawa) cells. Cancer Res 61: 6137-6144, 2001.

16. Hiroi H, Momoeda M, Inoue S, Tsuchiya F, Matsumi H, Tsutsumi O, Muramatsu M and Taketani Y: Stage-specific expression of estrogen receptor subtypes and estrogen responsive finger protein in preimplantational mouse embryos. Endocr $\mathrm{J}$ 46: 153-158, 1999.

17. Van Beveren C, van Straaten F, Curran T, Muller R and Verma IM: Analysis of FBJ-MuSV provirus and c-fos (mouse) gene reveals that viral and cellular fos gene products have different carboxy termini. Cell 32: 1241-1255, 1983.

18. Niwa K, Hashimoto M, Lian Z, Gao J, Tagami K, Yokoyama Y, Mori $\mathrm{H}$ and Tamaya $\mathrm{T}$ : Inhibitory effects of toremifene on $\mathrm{N}$-methyl-N-nitrosourea and estradiol-17ß induced endometrial carcinogenesis in mice. Jpn J Cancer Res 93: 626-635, 2002. 